\title{
Down-regulation of Epstein-Barr virus nuclear antigen 1 in Reed-Sternberg cells of Hodgkin's disease
}

\author{
G Khan, M A Naase
}

\begin{abstract}
Aims-To demonstrate Epstein-Barr virus (EBV) encoded nuclear antigen 1 (EBNA-1) gene expression in EBV associated disorders using a new monoclonal antibody (1H4-1) on routinely processed tissues.

Methods-The pressure cooker antigen retrieval method was used for the immunohistochemical demonstration of EBNA-1 gene expression in formalin fixed, EBV positive tissues from Hodgkin's disease, infectious mononucleosis, HIV associated non-Hodgkin's lymphomas, post-transplant lymphomas, and undifferentiated nasopharyngeal carcinoma (NPC). EBV encoded EBNA-2, latent membrane protein 1 (LMP-1) and BZLF-1 gene expression was also examined using commercially available monoclonal antibodies.
\end{abstract}

Results-Of the 34 EBER in situ hybridisation positive cases of Hodgkin's disease examined, none expressed EBNA-1 in the Reed-Sternberg cells. These cells were nevertheless strongly LMP-1 positive in all cases. Strong EBNA-1 staining was seen in all cases of EBER positive HIV associated non-Hodgkin's lymphoma (five of five), nasopharyngeal carcinoma (five of five), infectious mononucleosis (three of three), and post-transplant lymphoma (one of one). These cases also expressed LMP-1, EBNA-2 and BZLF-1, but at differing levels.

Conclusion-The pressure cooker antigen retrieval procedure is a sensitive and reliable adjunct to immunohistochemistry, especially with antibodies which are otherwise ineffective on routinely processed tissues. The EBNA-1 gene is not expressed at detectable levels in the malignant cells of Hodgkin's disease, but is consistently expressed in other EBV associated disorders. This finding has important implications for the role of EBNA-1 in the biology of EBV.

(f Clin Pathol 1995;48:845-848)

Keywords: Epstein-Barr virus, Reed-Sternberg cells, Hodgkin's disease.

Epstein-Barr virus (EBV), a lymphotropic herpesvirus, continues to attract considerable attention and with some justification. The virus is known to be the causative agent of infectious mononucleosis ${ }^{1}$ and has been implicated in an increasing range of human lymphoepithelial disorders, including Burkitt's lymphoma, nasopharyngeal carcinoma, post-transplant lympho- proliferations, oral hairy leucoplakia, HIV related lymphomas, Hodgkin's disease, and $T$ cell lymphomas. ${ }^{2-6}$ If the mechanism(s) by which EBV causes malignant transformation is elucidated, the possibility of preventing some of these malignant disorders could become a reality.

EBV is a ubiquitous DNA virus, carried asymptomatically by over $90 \%$ of individuals world wide. In vivo, the virus infects B lymphocytes and oropharyngeal epithelial cells. Infection of $\mathrm{B}$ cells is mediated by the binding of EBV to the cellular $145 \mathrm{kDa}$ glycoprotein CD21, which acts as the viral receptor. ${ }^{7}$ In $B$ lymphocytes the virus is thought to restrict its gene expression to EB nuclear antigen 1 (EBNA-1) and EB encoded RNAs (EBERs) only. ${ }^{8}$ This pattern of gene expression, referred to as latency type $\mathrm{I}$, is probably a strategy adopted by the virus in order to escape immune surveillance. ${ }^{9}$ When the immune system is perturbed, as in organ transplant recipients and in those with AIDS, EBV infected cells can proliferate unchecked and the infected cells express a range of viral latent gene products. ${ }^{10-13}$ Many of these proteins, in particular EBNA-2 and latent membrane protein 1 (LMP-1), are thought to participate in cell transformation. ${ }^{14-17}$ More recent data suggest that EBNA-1 may also be involved in this process. ${ }^{1819}$ EBNA-1 is a $65-95 \mathrm{kDa}$ DNA binding, non-immunogenic protein believed to be expressed in all EBV infected cells, where it is required for episome replication and persistence. ${ }^{20}$ Although EBNA-1 expression has been shown in EBV associated disorders using immunoblotting $^{2122}$ and reverse transcriptase polymerase chain reaction (RT-PCR), ${ }^{823}$ direct immunohistochemical demonstration has been hindered by the lack of suitable monoclonal antibodies reactive in paraffin wax embedded tissue. In this study we have examined a large series of EBV associated Hodgkin's disease cases, undifferentiated nasopharyngeal carcinomas (NPC), infectious mononucleosis, HIV related nonHodgkin's lymphomas, and one case of posttransplant lymphoma for EBNA-1 gene expression using a new antibody that is reactive in formalin fixed archival material.

\section{Methods}

Archival paraffin wax embedded tissues from a total of 48 cases were retrieved for analysis, including 34 cases of Hodgkin's disease, five cases of NPC, five cases of HIV associated nonHodgkin's lymphoma, three cases of EBV induced infectious mononucleosis, and one case of post-transplant lymphoma. All of these cases were known to be EBV positive as determined by EBER in situ hybridisation (ISH). The
Correspondence to: Dr G Khan. 
Hodgkin's disease and NPC cases have been included in our previous studies. ${ }^{24-26}$ Namalwa, B95-8 and an EBV transformed lymphoblastoid cell line were used as EBV positive controls. The Ramos cell line and five cases of reactive lymph nodes were used as negative controls.

\section{EBER ISH AND IMMUNOHISTOCHEMISTRY}

EBER ISH was carried out as described in detail elsewhere. ${ }^{24}$ The recently described pressure cooker antigen retrieval method was used as an adjunct to immunohistochemistry. ${ }^{27}$ Briefly, $5 \mu \mathrm{m}$ paraffin wax sections were dewaxed, endogenous peroxidase activity blocked in $\mathrm{H}_{2} \mathrm{O}_{2}$ /methanol and then transferred to boiling $0.01 \mathrm{M}$ sodium citrate solution ( $\mathrm{pH} 6.0)$ in a pressure cooker. The lid was secured and the pressure allowed to build up. The sections were treated for two minutes at maximum pressure. After rinsing in phosphate buffered saline, the sections were stained using the Vector "elite" Streptavidin-biotin peroxidase complex kit (Vector Laboratories, Peterborough, UK). The following primary monoclonal antibodies were used: CS1-4 (anti-LMP-1), PE2 (anti-EBNA-2), and BZ1 (anti-BZLF-1). All three clones were of mouse IgGl subtype and were used at a 1 in 20 dilution (Dako, High Wycombe, UK). EBNA-1 was detected using clone 1H4-1 (rat IgG) undiluted to a 1 in 10 dilution (kindly provided by $\mathrm{Dr}$ Friedrich Grässer, Institut fur Medizinsche Mikrobiologie und Hygiene, Universitatskliniken des Saarlandes, Homburg, Germany).

\section{Results}

CELL LINES

Initially, cytospins of the B95-8 (EBV + ) cell line were used as a positive control for the determination of EBV gene expression. Most of the cells expressed EBERs, EBNA-1 and EBNA-2. LMP-1 staining was observed in less than half of the cells and was most evident in the large binucleated cells. BZLF-1 expression, although very strong, was noted in less than $10 \%$ of the cells. Similar results were obtained when formalin fixed, paraffin wax embedded B95-8 cells were used with the pressure cooker method. Interestingly, the 1H4-1 (EBNA-1), PE2 (EBNA-2) and BZ1 (BZLF-1) clones do not work on formalin fixed material in standard immunostaining procedures; after treatment in a pressure cooker, however, strong nuclear staining was seen with all three antibodies. Strong staining with these antibodies was also seen in the EBV transformed lymphoblastoid cell line. Five cases of reactive lymph nodes used as EBV negative controls did not stain with any of these antibodies.

\section{TISSUES}

Of the 34 EBER ISH positive cases of Hodgkin's disease examined, none showed expression of EBNA-1 in the Reed-Sternberg cells, even with undiluted antibody (fig 1A). However, strong cytoplasmic and membrane staining for LMP-1 was seen in all cases. Interestingly, EBNA-1 staining in occasional small lymphocytes was observed in most of these cases. Fifteen of the 34 EBER and LMP-1 positive cases were also examined for EBNA-2 and BZLF-1 expression, but were negative for both (table). Of the five EBER positive cases of NPC, none were found to express LMP-1, EBNA-2 or BZLF-1, but all five expressed EBNA-1 (fig 1B). By contrast, the five cases of HIV related non-Hodgkin's lymphoma, three cases of infectious mononucleosis and the single case of post-transplant lymphoma examined expressed high levels of LMP-1, EBNA-1, EBNA-2, and BZLF-1 (fig 1C, fig 2). The proportion of cells expressing these proteins, however, varied from case to case. EBNA-1 and EBNA-2 expression was most widespread, while BZLF-1 expression was generally seen in less than $5 \%$ of the EBER positive cells. In one case of HIV associated non-Hodgkin's lymphoma, however, more than $75 \%$ of the EBNA-1 positive cells expressed BZLF-1, but less than $10 \%$ of the EBNA-1 positive

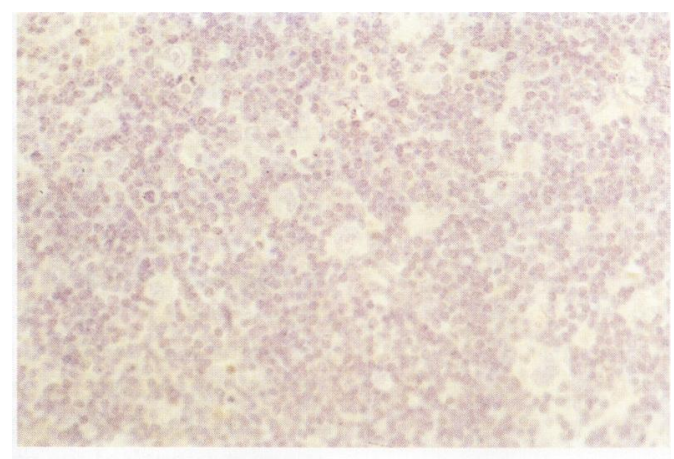

(A)

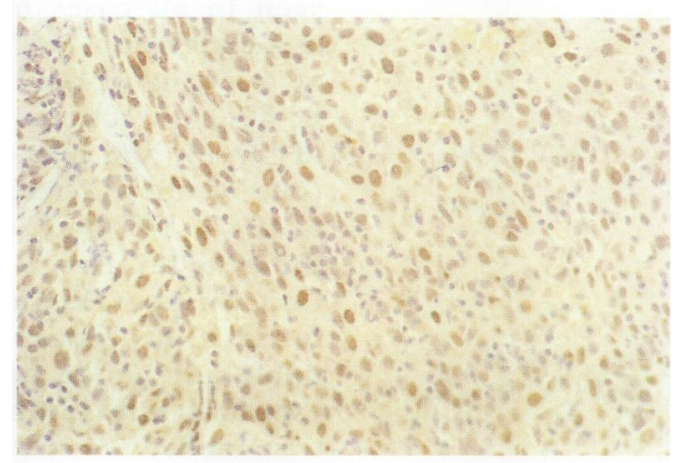

(B)

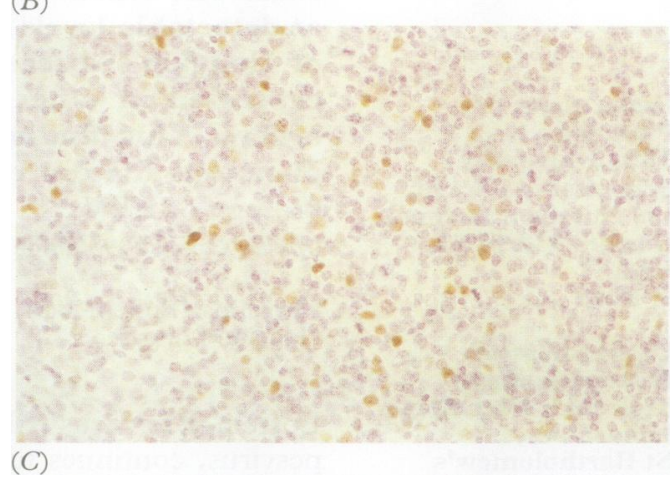

Figure 1 Immunoperoxidase staining for $E B V$ encoded EBNA-1. (A) Hodgkin's disease. The Hodgkin and Reed-Sternberg cells are clearly negative for this protein. (B) Undifferentiated NPC. Strong EBNA-1 staining can be seen throughout the malignant cell population. Strong nuclear staining for EBNA-1 is also evident in infectious mononucleosis $(\times 250)(C)$. 
$E B V$ gene expression in virus associated disorders

\begin{tabular}{|c|c|c|c|c|c|}
\hline Disorder & $\begin{array}{l}\text { EBER positive } \\
\text { cases }(n)\end{array}$ & $L M P-1$ & $E B N A-1$ & $E B N A-2$ & $B Z L F-1$ \\
\hline $\begin{array}{l}\text { Hodgkin's disease } \\
\text { NPC } \\
\text { HIV related non-Hodgkin's lymphoma } \\
\text { Infectious mononucleosis } \\
\text { Post-transplant lymphoma }\end{array}$ & $\begin{array}{r}34 \\
5 \\
5 \\
3 \\
1\end{array}$ & $\begin{array}{l}34 / 34 \\
0 / 5 \\
5 / 5 \\
3 / 3 \\
1 / 1\end{array}$ & $\begin{array}{l}0 / 34 \\
5 / 5 \\
5 / 5 \\
3 / 3 \\
1 / 1\end{array}$ & $\begin{array}{l}0 / 15 \\
0 / 5 \\
5 / 5 \\
3 / 3 \\
1 / 1\end{array}$ & $\begin{array}{l}0 / 15 \\
0 / 5 \\
5 / 5 \\
3 / 3 \\
1 / 1\end{array}$ \\
\hline
\end{tabular}

cells were EBER positive. Hence, a negative correlation between EBER expression and BZLF-1 expression was noted. This is in agreement with the hypothesis that EBERs are not expressed in permissively infected (BZLF-1 positive) cells. ${ }^{2829}$

EBNA-1, EBNA-2 and BZLF-1 staining was restricted to the nucleus in contrast to cytoplasmic and membrane staining seen for LMP-1 (fig 2). Interestingly, LMP-1 staining was most evident in large immunoblasts and binuclear cells. This observation was best seen in cases of infectious mononucleosis. It is possible

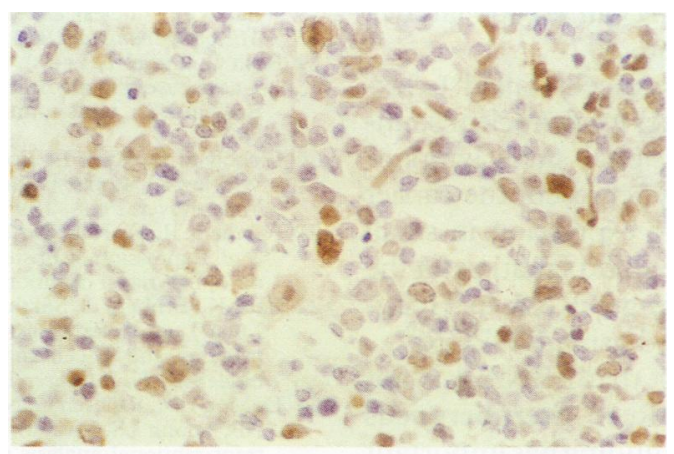

(A)
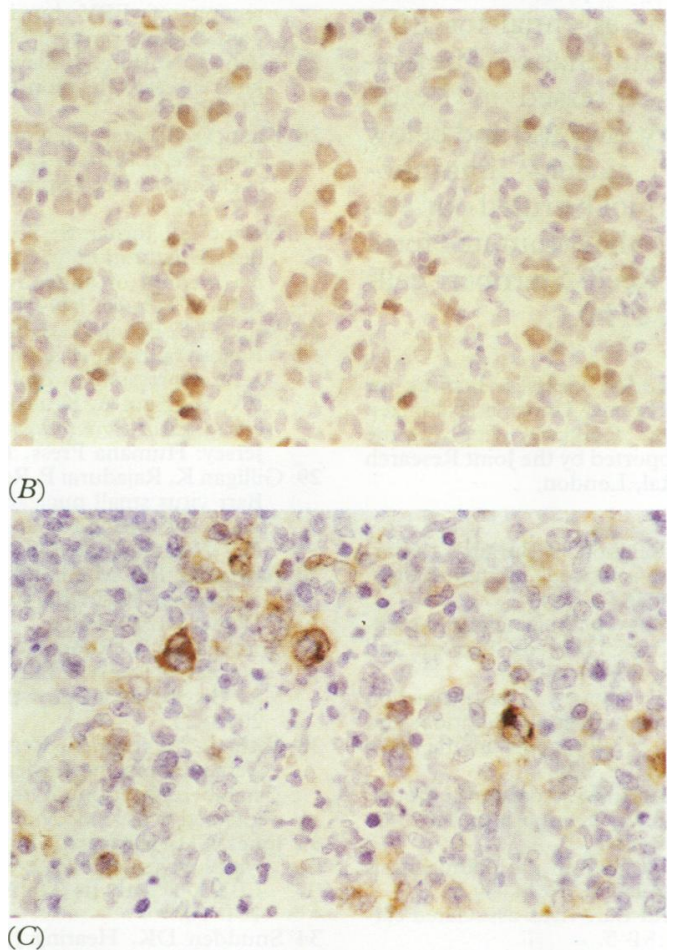

Figure 2 Immunoperoxidase staining for $E B V$ encoded latent proteins in a case of HIV associated non-Hodgkin's lymphoma: $(A) E B N A-1$, (B) EBNA-2 and (C) LMP-1. Lymphoma: (A) EBNA-1, (B) EBNA-2 and (C) LMP-1. in contrast to the membrane/cytoplasmic staining seen for LMP-1. Note that the LMP-1 immunostaining appears to be most evident in the binucleated cells $(\times 400)$. that LMP-1 is partly responsible for the morphological appearances of binucleated ReedSternberg-like cells which are frequently seen in many EBV associated lymphoproliferative conditions. $^{517}$

\section{Discussion}

EBV is among the best recognised DNA viruses implicated in human malignancies. In recent years the widespread availability of reagents such as EBV specific probes and monoclonal antibodies has allowed investigators to detect and analyse EBV infection at the cellular level..$^{30}$ The determination of EBV gene expression and the role of the viral proteins in the pathogenesis of EBV associated disorders are currently being unravelled. The latent proteins LMP-1 and EBNA-2 have been known for many years to be necessary for cell transformation, but more recently it has been demonstrated that EBNA-1 and EBNA-3A and -3C may also be essential for this process. ${ }^{181931}$

The hypothesis that EBNA-1 has oncogenic potential is intriguing. This nuclear phosphoprotein is thought to be the only viral protein consistently expressed in all EBV infected cells. ${ }^{20}$ Moreover, this is the only viral protein known to be expressed in Burkitt's lymphoma. ${ }^{9}$ EBNA-1 has been shown to be a DNA binding protein essential for both viral replication and episome maintenance..$^{32}{ }^{33}$ It binds to DNA as a homodimer at three different sites in the EBV genome, two of which are located in the or $\mathrm{P}$ region. ${ }^{33}$ Recently, it has been shown that EBNA-1 can also bind to several different species of RNA, including the EBV encoded RNA polymerase III transcript (EBER-1) ${ }^{34}$ Most of the functional activities of EBNA-1 have been localised to the $C$ terminus of the protein..$^{2034}$ Together, all these findings highlight the importance of EBNA-1 in EBV replication, persistence and cell transformation. Thus, this protein is thought to be essential for EBV survival.

The availability of a monoclonal antibody to EBNA-1 that is effective in routine formalin fixed, paraffin wax embedded tissues prompted us to examine the expression of this protein in EBV associated disorders, to confirm previous immunoblotting and RT-PCR studies. ${ }^{8223}$ Of the 34 EBER and LMP-1 positive cases of Hodgkin's disease tested, none expressed EBNA-1 in the Reed-Sternberg cells. By contrast, all of the EBV positive cases of NPC, infectious mononucleosis, HIV related nonHodgkin's lymphoma, and the single case of post-transplant lymphoma strongly expressed this protein. This finding was surprising and even more so when considering that Grässer et al, who supplied the antibody, observed EBNA-1 expression in a proportion of the EBV positive cases of Hodgkin's disease they had examined. ${ }^{35}$ To determine whether technical differences 
contributed to the conflicting results found in the two laboratories, we also tried the microwave antigen retrieval procedure used by the German group, but the results were unchanged. The Reed-Sternberg cells still remained negative for EBNA-1. We consistently found the pressure cooker method to be more sensitive and reliable. In fact, using this method, we were able to demonstrate the expression of EBNA-2 and BZLF-1 in cases of infectious mononucleosis, HIV associated non-Hodgkin's lymphoma, and post-transplant lymphoma using the monoclonal antibodies PE2 and BZ1, respectively. These antibodies are ineffective in formalin fixed tissue using standard immunohistochemistry. The finding of BZLF-1 expression in these lymphoproliferative conditions is worth noting. BZLF-1 is an immediate early protein, the expression of which is an indicator of the transition from the latent to the lytic cycle. ${ }^{20}$ Hence, the expression of this protein in these disorders suggests that, although EBV infection is essentially non-lytic, a small proportion of the infected cells can escape latency and undergo lytic infection.

Although Reed-Sternberg cells failed to express EBNA-1, in most cases weak nuclear staining was observed in occasional small lymphocytes. These cells probably represent the carrier state. ${ }^{8}$ Moreover, EBNA-1 expression in small lymphocytes could provide an explanation for the finding of EBNA-1 messenger RNA in Hodgkin's disease tissue, detected using RT-PCR. ${ }^{23}$

In conclusion, we report that EBNA-1 is not expressed in EBV infected Reed-Sternberg cells in Hodgkin's disease. This finding has important implications for the generally held hypothesis that EBNA-1 is universally expressed in EBV infected cells and that it is essential for EBV replication and episomal maintenance. The possibility that EBNA-1 is expressed in ReedSternberg cells, but at a very low level and below the detection limit of current immunohistochemical methods cannot be ruled out. Alternatively, it is also possible that a mutated form of EBNA-1 is expressed in Reed-Sternberg cells which is not recognised by $1 \mathrm{H} 4-1$.

We would like to thank Dr Friedrich Grässer, Institut fur Medizinsche Mikrobiologie und Hygiene, Universitatskliniken des Saarlandes, Homburg, Germany, for kindly supplying the 1H4-1 antibody. This work was supported by the Joint Research Board of St Bartholomew's Hospital, London.

1 Henle G, Henle W, Diehl V. Relation of Burkitt's tumorassociated herpes-type virus to infectious mononucleosis. Proc Natl Acad Sci USA 1968;56:94-101.

2 Miller G. Epstein-Barr virus biology, pathogenesis and medical aspects. In: Fields BN, Knipe DM, eds. Virology. 2nd edn. New York: Raven Press, 1990:1921-57.

3 Pallesen G, Hamilton-Dutoit SJ, Zhou X. The association of Epstein-Barr virus with T-cell lymphoproliferations and Hodgkin's disease: two new developments in the EBV Hodgkin's disease: two new developme
field. Adv Cancer Res 1993;62:179-239.

4 Rickinson AB. EBV infection and EBV-associated tumours. Society of General Microbiology Symposium 1994;51: Society

5 Khan G, Coates PJ. The role of EBV in the pathogenesis of Hodgkin's disease. 7 Pathol 1994;174:141-9.

6 Niedobitek G, Herbst H. Epstein-Barr virus-associated carcinomas. EBV Report 1994;1:81-5.

7 Nemerow G, Luxembourg A, Cooper N. CD21/CR2: Its role in EBV infection and immune function. EBV Report 1994;1:59-64.

8 Tierney RJ, Steven N, Young LS, Rickinson AB. EpsteinBarr virus latency in blood mononuclear cells: analysis of viral gene transcription during primary infection and in carrier state. $\mathcal{F}$ Virol 1994;68:7374-85.

9 Rickinson AB, Murray RJ, Brooks S, Griffin H, Moss DJ,
Masucci MG. T cell recognition of Epstein-Barr virus associated lymphomas. Cancer Surv 1992;13:53-79.

10 Young $L$, Alfieri C, Hennessy $K$, Evans $H$, O'Hara $C$ Anderson KC, et al. Expression of Epstein-Barr virus ransformation-associated genes in tissues of patients with EBV lymphoproliferative disease. $N$ Engl $₹$ Med 1989;321 1080-5.

11 Thomas JA, Hotchin NA, Allday MJ, Amlot P, Rose M Yacoub M, et al. Immunohistology of Epstein-Barr virusassociated antigens in B-cell disorders from immunocompromised individuals. Transplantation 1990;49. 944-53.

12 Gratama JW, Zutter MM, Minarovits J, Oosterveer MA, Thomas ED, Klein G, et al. Expression of Epstein-Barr virus-encoded growth-transformation-associated proteins virus-encoded growth-transformation-associated proteins cipients. Int 7 Cancer 1994;47:188-92.

13 Pallesen G, Hamilton-Dutoit S, Rowe M, Lisse I, Ralfkiaer $\mathrm{E}$, Sandvej K, et al. Expression of Epstein-Barr virus replicative proteins in AIDS-related non-Hodgkin' lymphoma cells. F Pathol 1991;165:289-99.

14 Wang D, Liebowitz D, Kieff E. An EBV membrane protein expressed in immortalized lymphocytes transforms established rodent cells. Cell 1985;43:831-40.

15 Wang $F$, Gregory $C D$, Rowe $M$, Rickinson $A B$, Wang $D$, Birkinbach M, et al. Epstein-Barr virus nuclear antigen 2 specifically induces expression of the B cell activation antinen CD23. Proc Natl Acad Sci USA 1987;84:3452-6.

16 Rickinson A, Young L Rowe M. Influence of the EpsteinBarr virus nuclear antigen EBNA-2 on the growth phenoBarr virus nuclear antigen EBNA-2 on the growth pheno-

17 Knecht H, Brousset P, Bachmann E, Sandvej K, Odermatt BF. Latent membrane protein 1: A key oncogene in EBVrelated carcinogenesis. Acta Haematol 1993;90:167-71.

18 Wilson J, Levine AJ. The oncogenic potential of EpsteinBarr virus nuclear antigen 1 in transgenic mice. Curr Top Microbiol Immunol 1992;182:375-84.

19 Roth G, Curiel T, Lacy J. Epstein-Barr viral nuclear antigen 1 antisense oligodeoxynucleotide inhibits proliferation of Epstein-Barr virus-immortalized B cells. Blood 1994;84: 582-7.

20 Liebowitz D, Kieff E. Epstein-Barr virus. In: Roizman B, Whitley RJ, Lopez C, eds. The human herpesviruses. New York: Raven Press, 1993:107-72.

21 Fahraeus R, Fu H-L, Ernberg I, Finke J, Rose M, Klein G et al. Expression of Epstein-Barr virus encoded proteins in et al. Expression of Epstein-Barr virus encoded proteins in

22 Falk K, Ernberg I, Sakthivel R, Davis J, Christensson B, Luka J, et al. Expression of Epstein-Barr virus-encoded proteins and B-cell markers in fatal infectious mononucleosis. Int $\mathcal{F}$ Cancer 1990;46:976-84.

23 Deacon EM, Pallesen G, Niedobitek G, Brooks L, Rickinson AB, Young LS. Epstein-Barr virus and Hodgkin's disease: transcriptional analysis of virus latency in the malignant cells. F Exp Med 1993;177:339-49.

24 Khan G, Coates PJ, Kangro HO, Slavin G. Epstein-Barr virus (EBV) encoded small RNAs: Targets for the detection of EBV by in situ hybridization with oligonucleotide probes. 7 Clin Pathol 1992;45:616-20

25 Khan G, Norton AJ, Slavin G. Epstein-Barr virus in Hodgkin's disease: Relation to age and subtype. Cancer 1993, kin's disease:

26 Khan G, Coates PJ, Gupta RK, Kangro HO, Slavin G. Presence of Epstein-Barr virus in Hodgkin's disease is no exclusive to Reed-Sternberg cells. Am $\mathcal{F}$ Pathol 1992;140: 757-62.

27 Norton AJ, Jordan S, Yeomans P. Brief, high-temperature heat denaturation (pressure cooking): A simple and effective method of antigen retrieval for routinely processed tissues. F Pathol 1994;173:371-9.

28 Young LS, Brooks L, Gilligan K, Dawson CW, Resnick L Raab-Traub N, et al. Epstein-Barr virus replication and gene expression in oral "hairy" leukoplakia. In: Ablash gene expression in oral "hairy" leukoplakia. In: Ablash DV, Faggioni A, Krueger GRF, Pagano JS, Pearson GR, Jersey: Humana Press, 1989:329-31.

29 Gilligan K, Rajadurai P, Resnick L, Raab-Traub N. EpsteinBarr virus small nuclear RNAs are not expressed in permissively infected cells in AIDS-associated leukoplakia. Proc Natl Acad Sci USA 1990;87:8790-4.

30 Ambinder RF, Mann RA. Detection and characterization of Epstein-Barr virus in clinical specimens. Am $₹$ Pathol 1994;145:239-52.

31 Tomkinson B, Robertson E, Kieff E. Epstein-Barr virus nuclear proteins EBNA-3A and EBNA-3C are essential for B-lymphocyte growth transformation. $\mathcal{F}$ Virol 1993;67: 2014-25.

32 Yates JL, Warren N, Reisman D, Sugden B. A cis-acting element from the Epstein-Barr viral genome that permits stable replication of recombinant plasmids in latentlystable replication of recombinant plasmids in latently-

33 Jones CH, Hayward SD, Rawlins DR. Interaction of the lymphocyte-derived Epstein-Barr virus nuclear antigen lymphocyte-derived Epstein-Barr virus nuclear antigen EBNA-1

34 Snudden DK, Hearing J, Smith PR, Grässer FA, Griffin BE. EBNA-1, the major nuclear antigen of Epstein-Barr virus, resembles "RGG" RNA binding proteins. EMBO F 1994;13:4840-7.

35 Grässer FA, Murray PG, Kremmer E, Klein K, Remberger $\mathrm{K}$, Feiden W, et al. Monoclonal antibodies directed against the Epstein-Barr-encoded nuclear antigen 1 (EBNA1) immunohistologic detection of EBNA1 in the malignan cells of Hodgkin's disease. Blood 1994;84:3792-8. 